The Canadian Journal of Higher Education

La revue canadienne d'enseignement supérieur

Volume XXXI, No. 1, 2001 pages 121-140

\title{
The Performance of "Gifted" High School Students in University
}

\section{J. PAUL GRAYSON}

York University

\section{ABSTRACT}

In Ontario, school boards are required to provide opportunities so that "gifted" students (i.e., those with exceptional abilities) can obtain learning experiences that are beyond those offered in regular classes. This study follows graduates of regular and gifted programs over four years of studies at York University in Toronto. Overall, it is found that having participated in a gifted program in high school does not result in increased levels of achievement in university; however, graduates of gifted high school programs have slightly higher self-assessed thinking and reasoning and problem-solving skills and are marginally faster in credit completion than other students. These findings aside, it is difficult to argue that participation in a high school gifted program confers an advantage students once they get to university.

\section{RÉSUMÉ}

En Ontario, les conseils scolaires doivent donner l'occasion aux élèves surdoués (c'est-à-dire, ceux qui ont des capacités exceptionnelles) d'apprendre au delà de ce qui est offert dans les classes régulières. Dans le cadre de cette étude, nous avons suivi de près les diplômés des programmes réguliers et spéciaux (prévus pour les élèves surdoués) 
pendant quatre ans à l'Université York de Toronto. Dans l'ensemble, il a été trouvé que la participation dans un programme spécial à l'école secondaire ne donne pas nécessairement une augmentation du rendement à l'université; toutefois, les diplômés d'un programme spécial sont légèrement plus compétents en autoévaluation, raisonnement et résolution de problèmes et un peu plus rapides que les autres étudiants dans l'obtention de crédits pour terminer leurs études. Mis à part ces résultats, il est difficile de démontrer que les élèves ayant participé à un programme spécial sont mieux préparés pour faire des études universitaires.

\section{INTRODUCTION}

In their introduction to a series of articles on "giftedness," psychologists Sternberg and Davidson (1986) argue that, "giftedness is something we invent, it is not something we discover" (p. 3). More concretely, what passes as giftedness in one society may not necessarily qualify in another (i.e., being a skilled plains hunter will not further a career in the metropolis). From a sociological perspective it can be added that what is accepted as giftedness in one class or group in society may not be shared by all. This line of thinking is consistent with analyses of multiple intelligences and the ways in which particular societies foster their development (Gardner, 1984, 1985; Sternberg, 1990).

Usually, the dominant view of giftedness is one that is articulated and propagated by those who enjoy a differential amount of power in certain institutions. In contemporary Western societies, institutions that contribute to both dominant definitions of giftedness and, in some instances, offer alternative conceptualizations include churches, political parties, schools, colleges, universities, government ministries, and special interest groups such as the Association for Bright Children in Ontario.

While giftedness is socially constructed, the process of construction is not always clear. (For an examination of the process in a number of societies, see Heller \& Feldhusen, 1986). For some, the social construction process is based on the belief that giftedness is an individual property. As a result, it is necessary to identify those with such properties so 
that they can be placed in the appropriate programs. For others, environmental circumstances lead to behaviours that may be defined as gifted. For these individuals, it is necessary to provide environments suitable to the emergence of giftedness. In contrast to each of these positions, other researchers prefer one that considers the interactive effect of both personal and environmental factors.

In Ontario, Bill 82, an amendment to the Education Act of 1974 (Smyth, 1984), defined the gifted as students who display:

an unusually advanced degree of general intellectual ability that requires differentiated learning experiences of a depth and breadth beyond those normally provided in the regular program to satisfy the level of potential indicated. (p. 145)

In specifying this definition, the Bill side-steps the etiological issue noted above. Instead, it takes an observed "advanced degree of general intellectual ability" as a starting point. Whether the observed intellectual ability is an individual property that would have developed even under adverse conditions, or whether the ability is a result of favourable environmental contexts, is not addressed (nor could it be). Had the issue been addressed, and had it been recognized that individual properties go only so far in explaining an "advanced degree of general intellectual ability," the implications of the recognition would have gone well beyond the Education Act.

Consistent with the underlying conception of giftedness, within the broad legislative framework established by Bill 82 , individual school boards are given the freedom to establish processes that will have the net effect of yielding individuals deemed gifted. In accordance with the regulations accompanying Bill 82, the first step in constructing giftedness, nomination, can be taken by teachers, parents, individuals in the community, or the student him/herself - each can make a claim for the giftedness of the student under consideration. The rationale for such assertions can vary from a high I.Q. score to the belief on the part of a student's parents that their child is not realizing his/her full potential in traditional learning situations.

The second step in the construction of giftedness involves a Special Education Identification Placement and Review Committee (IPRC) that 
may include a principal, supervisory officer and medical practitioner. On the basis of what the school board in question deems relevant evidence the committee may or may not designate the nominated student as gifted. In the event that a student is defined as gifted, he or she has the option of participating in various special "enriched" programs. Should there be dissatisfaction with the decision of the IPRC, the Bill provides for an appeal process. It might be noted that a student who emerges as gifted through the process in one school board may not so emerge in another board. (For a general discussion of the process in Ontario see: ; Anonymous, 1981; Government of Ontario, 1990; Hodder, 1984; Keeton, 1983; Smyth, 1984).

As noted by Hodder (1984), the Ministry of Education initially made some funds available to school boards to help cover costs associated with providing special programs for the gifted; however, given the ways in which school boards organize their budgets, it is not possible to gain a true picture of all costs associated with the provision of such programs. Any complete assessment of overall costs, among other measures, would have to include costs of special teacher training and hiring, the costs associated with determining giftedness, the provision of, in many instances, additional classroom space, the provision of additional books and supplies for the gifted, the costs of additional field trips taken by the gifted, and so on.

Opposition to programs for the gifted comes from at least two sources. First, many who oppose special programs for the gifted point to what they regard as a selection process that is biased in favour of children from high socio-economic families. Second, some critics feel that the resources required to sustain programs for the gifted could be put to better use in meeting the common needs of all students.

While there is no hard evidence with regard to the first of these concerns as they relate to education for the gifted in Ontario, it has long been known that, for example, scores on I.Q. tests are as much a measure of family income as anything else (Sternberg, 1985; Sternberg \& Wagner, 1986). Moreover, there is some anecdotal evidence that in many boards, schools located in affluent areas yield more gifted students than schools in relatively poor areas. With respect to the second concern, 
there is hard evidence to show that some school boards have increasing difficulty in meeting needs shared by all students.

One of the difficulties in studying gifted students in general, and gifted students in Ontario in particular, is that there is no commonly accepted definition of giftedness. For example, Renzulli (1978) argues that gifted children have at least a moderate level of general intelligence, high task commitment, and creativity. By contrast, according to Tannenbaum (1983):

giftedness in children...denotes their potential for becoming critically acclaimed performers or exemplary producers of ideas in spheres of activity that enhance the moral, physical, social, intellectual, or aesthetic life of humanity. (p. 87)

Even if definitional agreement existed at the conceptual level, it is likely that it would be very difficult to obtain consensus on how such concepts could be operationalized in a way that would be politically acceptable to school boards across the province.

In addition to problems of definition and measurement, it must be recognized that many individuals who have left their marks on history have been unremarkable in childhood and/or adolescence. For example, even when he was in college, the musical composer Igor Stravinsky was uninterested in the skills of musical composition. The British mathematician, G.H. Hardy, only began to show promise during the course of his university education. Similarly, the visual artists Paul Klee and Jean Miro demonstrated no talent until their early adulthood (Walters \& Gardner, 1986). It is possible that individuals such as these would not have been admitted into programs for the gifted in Ontario.

Given that individuals develop at different speeds, we must avoid assuming that students who are not admitted to gifted programs will not be successful in various realms of activity. In view of difficulties such as the foregoing, for heuristic reasons, we can define the gifted as those who are the products of a system designed to identify the gifted, much in the same way as we define graduates of our universities as "educated."

Whatever the case regarding the appropriateness of programs for the gifted, in Canada, no studies have focussed on their short- and mediumterm outcomes. Among others, these outcomes might include success in 
university or in jobs and careers, good citizenship, and psychological well-being. Moreover, within the university context, it is possible to examine a broad range of possible outcomes of a gifted program ranging from creativity, to analytical thinking, to effective communication. Although, as noted earlier, we are hampered by the absence of a specific and acceptable definition of giftedness in Ontario, it is reasonable to assume that if gifted programs enrol students with an "advanced degree of intellectual ability," graduates would do better in university than students coming out of regular programs with the same Ontario Academic Credit (OAC) marks. Should this not be found, we might question the adequacy of the system in Ontario that identifies gifted students.

Based on a four-year longitudinal study, this article will focus on the university achievement levels and skill assessments of graduates of regular and gifted programs attending York University in Toronto between 1994 and 1998. The data will show that while graduates of gifted programs complete slightly more credits than other students, there are no differences in the academic achievement levels of gifted compared to other high school graduates with similar OAC marks. Graduates of gifted programs, however, have slightly higher self-assessed thinking and reasoning and problem-solving skills than other students.

\section{THE SAMPLE}

Located on the northern fringe of Metropolitan Toronto, York University has approximately 40,000 full- and part-time students. Of students in first year, only $10 \%$ live in residence on campus and $70 \%$ live with their parents. Approximately half of first year students come from families in which the average family income is below the provincial average and $72 \%$ are of European descent.

At the end of their first year, in February and March of 1995, surveys were sent to all first year students who in 1994 entered the Schulich School of Business (SSB), Environmental Studies, Fine Arts, and Glendon College. Because of its large size, only a sample of students was selected from the Faculty of Arts. This procedure resulted in a sample size of 1,865 and an overall response rate of $64 \%$. At the end of second year, in 1996, the questionnaire used in the 1995 study was again 
mailed to all students who entered in 1994 and who remained in SSB, Environmental Studies, Fine Arts, Glendon College, and Pure and Applied Science. In Arts, the original sample of respondents selected in 1995 was re-surveyed. The total number of respondents to the survey was 1,546 for a completion rate of $59 \%$. The 1997 sampling procedure was the same as in 1996. A total of 1,217 students participated in the survey for a response rate of $52 \%$.

By the end of 1997, 761 students had replied to all three end-of-year surveys carried out in 1995, 1996, and 1997. At the conclusion of the fourth year of study in 1998,98 of the 761 students who had responded to the three end-of-year surveys had graduated or left the university. Completed questionnaires were obtained from 513 of the students who had responded to the previous three surveys who had not yet graduated or left the university. This number represents a response rate of $77 \%$. Once adjustments are made for the number of students who left the university over the study period and, as a consequence, would not qualify for inclusion in the surveys, the survey retention rate between first and fourth years was 55\%. (For more details on this calculation, see Grayson, 1999.)

While there are no Canadian data with which to make comparisons, research conducted in the United States suggests that survey retention rates such as the foregoing are good. For example, Dey (1997) shows that in 1987 it was possible to retain only $26 \%$ of the participants in a large U.S. panel study of university students started in 1983. In 1989 only $23 \%$ of students who became involved in a similar panel study started in 1985 remained. Finally, in 1991, only $21 \%$ of students in a panel study started in 1987 stayed with the project. These and other data presented by Dey show that panel attrition in studies of students is high and that it is increasing with time.

\section{WHO ARE THE GIFTED?}

As noted earlier, for purposes of this study, students are considered gifted if they have been through a school board process that defines them as gifted. Of the students who responded to all four surveys, $85 \%$ graduated from regular high school programs, $11 \%$ were graduates of gifted 
programs, and $4 \%$ came from private schools. Because of small numbers, those who graduated from private schools were removed from analysis.

It is important to recognize that in gifted and regular program graduates came from a wide range of schools. As a result, we can safely assume that any observed overall effects of type of program on achievement and other measures are not the effects of programs in particular schools. We cannot assume, however, that gifted high school students attending York are a representative sample of gifted students in the province.

In the introduction, it was noted that some critics believe that placement in a gifted program has as much to do with family income as with anything else; however, the figures in Table 1 show that while only $5 \%$ of students from the lowest income category (less than or equal to $\$ 25,999$ ) come from gifted programs, with the exception of students with family incomes from $\$ 75,000$ to $\$ 99,999$ (23\% of whom graduated from gifted programs) the numbers for the other three income categories who participated in gifted programs are more or less the same (around $11 \%$ ). In short, while low income students are under-represented among the gifted, there is no consistent relationship between income and having participated in a gifted program; however, chi-square for the table is not statistically significant (.095).

Other analyses, not shown in table form, indicate that $10 \%$ of females and $14 \%$ of males had been defined as gifted. Although differences are small, chi-square for these differences is statistically significant. In addition, $0 \%$ of Black students came from gifted programs while the highest number of the gifted (14\%) are found among those described as "other non-European" (i.e., not Black, not South Asian, not Chinese, and not European). The figures for gifted students of South Asian, Chinese, and European origins are $7 \%, 4 \%$, and $13 \%$ respectively. Because of the small numbers in some groups, and the fact that chi-square is not statistically significant, these findings should be treated cautiously.

Taken collectively, the information presented in this section suggests that being defined as gifted may be related somewhat to family income, gender, and ethno-racial origin. However, before definitive statements 
Table 1

\section{High School Program by Family Income}

\begin{tabular}{|c|c|c|c|c|c|}
\hline & LE \$25,999 & $\begin{array}{c}\$ 26,000 \text { to } \\
\$ 49,999\end{array}$ & $\begin{array}{c}\$ 50,000 \text { to } \\
\$ 74,999\end{array}$ & $\begin{array}{c}\$ 75,000 \text { to } \\
\$ 99,999\end{array}$ & GE $\$ 100,000$ \\
\hline Regular & $95 \%$ & $89 \%$ & $90 \%$ & $77 \%$ & $86 \%$ \\
\hline Gifted & $5 \%$ & $11 \%$ & $10 \%$ & $23 \%$ & $14 \%$ \\
\hline \multirow[t]{2}{*}{ Total } & $100 \%$ & $100 \%$ & $100 \%$ & $100 \%$ & $100 \%$ \\
\hline & $(60)$ & (114) & (96) & (39) & $(162)$ \\
\hline Chi squa & sig. $=.095$ & & & & \\
\hline
\end{tabular}

can be made, it would be necessary to conduct studies based on larger numbers, and a wider selection, of students from gifted programs.

\section{OBJECTIVE MEASURES OF ACHIEVEMENT}

The Ontario Academic Credit (OAC) marks of gifted and regular program students are $83.9 \%$ and $79.5 \%$ respectively. These differences are statistically significant at the .000 level. Independent of these differences in grades, given the fact that gifted programs' are intended to recruit, and deal with the needs of, students with an "advanced degree of intellectual ability," it can be expected that graduates of gifted programs would have higher levels of academic achievement in university than other students with similar OAC marks. In essence, the benefits of a gifted education would add value over and above what is reflected in OAC marks.

In order to see if this were true, a repeated measures analysis of variance was carried out in which sessional grade point average (GPA), as taken from administrative records, was the dependent variable. (At York, GPA ranges from 0 to 9 where 0 means failure and 9 is $A+$.) The independent variables were OAC marks, also taken from administrative records, and the high school program from which students graduated (regular or gifted) as determined through survey responses. The results of this analysis are found in Table 2. 
Table 2

Sessional GPA by Year and High School Program

\begin{tabular}{|c|c|c|c|c|c|}
\hline \multicolumn{2}{|c|}{ Sessional GPA by Year } & \multicolumn{4}{|c|}{ Sessional GPA by High School Program } \\
\hline Year & GPA & Regular & Gifted & $\begin{array}{c}\text { Eta }^{2} \\
\text { Program }\end{array}$ & $\begin{array}{l}\mathrm{Eta}^{2} \\
\mathrm{OAC} \\
\end{array}$ \\
\hline Year 1 & 5.91 & & & & \\
\hline Year 2 & 5.99 & & & & \\
\hline Year 3 & 6.31 & & & & \\
\hline Year 4 & 6.31 & & & & \\
\hline Overall & 6.09 & 6.13 & 6.15 & .00 & .27 \\
\hline Sig. F & .000 & .884 & & & .000 \\
\hline$\overline{\mathrm{N}}$ & 455 & 400 & 55 & & \\
\hline
\end{tabular}

The first column of the table provides information on the sessional GPA of all students for each year of study. It can be seen that the average GPA in the first year of study is 5.91 (or a B). Thereafter, it increases slightly yet progressively to a high of 6.31 in the third and fourth years of study. The "Overall" GPA (6.09) is an average of scores over the four years. The significance level for $\mathrm{F}(.000)$ indicates that these differences are unlikely to have occurred by chance. In essence, the GPAs increase with level of study.

Columns three and four provide information on the scores of graduates of regular and gifted programs averaged over the four years of study. Once adjustments have been made for OAC marks, the GPAs of students from regular and gifted programs are 6.13 and 6.15 respectively. The .884 significance level of $F$, as shown in column three, indicates that these small differences in scores could have occurred by chance. In essence, there are no overall differences in academic achievement that can be related to high school programs.

A more precise estimation of the relationship between program and GPA is provided by eta squared as found in column five, 'eta ${ }^{2}$.' The .00 value for eta squared indicates that there is no relationship between program and GPA. The significance level of F (.884) indicates that this level of association is not significant. 
Table 3

Sessional Credits by Year and High School Program

\begin{tabular}{|c|c|c|c|c|c|}
\hline \multicolumn{2}{|c|}{ Credits by Year } & \multicolumn{4}{|c|}{ Credits by High School Program } \\
\hline Year & Credits & Regular & Gifted & $\begin{array}{c}\text { Eta }^{2} \\
\text { Program }\end{array}$ & $\begin{array}{l}\mathrm{Eta}^{2} \\
\mathrm{OAC}\end{array}$ \\
\hline Year 1 & 27.4 & & & & \\
\hline Year 2 & 25.5 & & & & \\
\hline Year 3 & 24.5 & & & & \\
\hline Year 4 & 22.7 & & & & \\
\hline Overall & 25.0 & 24.8 & 26.2 & .02 & .11 \\
\hline Sig. F & .164 & .000 & & & .000 \\
\hline $\bar{N}$ & 455 & 400 & 55 & & \\
\hline
\end{tabular}

By comparison, the value of eta squared for OAC marks is greater than for program (.27) and is statistically significant at the .000 level. In essence, while program has no effect on GPA, OAC marks have a moderate effect on the sessional GPA. Overall, these findings show that once adjustments have been made for OAC marks, graduates of high school gifted programs achieve grades similar to those of other students - their participation in a gifted program did not give them an advantage in university.

A second aspect of university achievement that can be examined is the number of credits students complete in a session (six credits equal one full course). As shown in Table 3, the number of completed credits declines progressively from 27.4 in the first year to 22.7 in the fourth. This difference, however, is not statistically significant (.164). By comparison, differences based on high school program of study are statistically significant (.000). Moreover, there are slight differences in the number of credits completed by graduates of gifted programs (26.2) and graduates of regular programs (24.8). Nonetheless, as shown by eta squared (.02), the relationship between program and completed credits, while statistically significant, is weak. With an eta squared of .11 and a level of significance of .000 , the connection between OAC marks and number of completed credits is higher than between program and 
completed credits. Overall, the information in Table 2 indicates that graduates of gifted programs complete slightly more credits than other students. The effect of high school program on completed credits, however, is weak.

In terms of the objective measures of achievement examined in this section, it is clear that having graduated from a gifted program does not result in higher marks in university. In addition, there is only a marginal difference in completed credits that can be traced to having participated in a gifted high school program. As a result, in these two areas, it can be concluded that high school gifted programs have minimal implications for how students will fare in university.

\section{SKILLS DEVELOPMENT}

There is an increasing amount of evidence supporting the validity of self-assessments of skills and knowledge (Baird, 1976; Berdie, 1971; Dumont \& Troelstrup, 1980; Evers \& Associates, 1993; McMorris \& Ambrosino, 1973; Pike, 1994, 1995a, 1995b; Pohlmann \& Beggs, 1974). As a result, in addition to objective measures of achievement made available through administrative records, information on self-assessments of skills was obtained through survey questions. Students were presented with a general question that asked, "Compared to other students you know at York at your level, how do you rate your competence on each of the following?" Included among the options were:

- Thinking and reasoning skills

- Problem solving skills

- Planning and organizing skills

- Communication skills

- Interpersonal and communication skills

- Quantitative/mathematical skills

Students rated themselves on a five point scale where 1 meant"extremely low" and 5 meant "extremely high."

The information presented in Table 4 shows that there is very little difference in self assessments of thinking and reasoning skills between years one and four. In the former the overall rating is 3.84; in the latter 3.93. These differences are not statistically significant. There are, 
Table 4

\section{Thinking and Reasoning Skills by Year and High School Program}

\begin{tabular}{|c|c|c|c|c|c|}
\hline \multicolumn{2}{|c|}{ Skills by Year } & \multicolumn{4}{|c|}{ Skills by High School Program } \\
\hline Year & Skills & Regular & Gifted & $\begin{array}{c}\text { Eta }^{2} \\
\text { Program }\end{array}$ & $\begin{array}{l}\mathrm{Eta}^{2} \\
\text { OAC }\end{array}$ \\
\hline Year 1 & 3.84 & & & & \\
\hline Year 2 & 3.83 & & & & \\
\hline Year 3 & 3.89 & & & & \\
\hline Year 4 & 3.93 & & & & \\
\hline Overall & 3.87 & 3.83 & 4.19 & .05 & .01 \\
\hline Sig. F & .399 & .000 & & & .135 \\
\hline $\mathrm{N}$ & 447 & 394 & 53 & & \\
\hline
\end{tabular}

however, differences over all four years in the scores of students from regular (3.83) and gifted (4.19) programs. Moreover, these differences are significant at the .000 level. In addition, the eta squared for the impact of program (.05) is slightly higher than that for OAC marks (.01). While the former is statistically significant (.000), the latter is not (.135). In essence, students from gifted programs have somewhat better selfassessed thinking and reasoning skills.

Similar conclusions emerge when problem solving skills are examined. Information in Table 5 shows that there is very little change between first (3.66) and fourth (3.73) years. Graduates of gifted programs, however, score higher than students from regular programs (3.68). These differences are significant at the .000 level; moreover, the .05 (F significant at .000 level) and .01 values of eta squared for program and OAC marks (significant at the .018 level) respectively indicate that the former has more of an impact on skills than the latter. The effect of each, however, is low.

When planning and organizing skills are examined (Table 6) once again there is little change between first (3.78) and fourth (3.90) years (significance of $\mathrm{F}$ is .521). There are, in addition, no statistically significant differences based on program: the scores for graduates of regular and gifted programs are 3.84 and 3.88. The value of eta squared for program 
Table 5

Problem-Solving Skills by Year and High School Program

\begin{tabular}{|c|c|c|c|c|c|}
\hline \multicolumn{2}{|c|}{ Skills by Year } & \multicolumn{4}{|c|}{ Skills by High School Program } \\
\hline Year & Skills & Regular & Gifted & $\begin{array}{c}\text { Eta }^{2} \\
\text { Program }\end{array}$ & $\begin{array}{l}\mathrm{Eta}^{2} \\
\mathrm{OAC}\end{array}$ \\
\hline Year 1 & 3.66 & & & & \\
\hline Year 2 & 3.72 & & & & \\
\hline Year 3 & 3.74 & & & & \\
\hline Year 4 & 3.81 & & & & \\
\hline Overall & 3.73 & 3.68 & 4.09 & .05 & .01 \\
\hline Sig. F & .477 & .000 & & & .018 \\
\hline $\mathrm{N}$ & 444 & 391 & 53 & & \\
\hline
\end{tabular}

Table 6

Planning and Organizing Skills by Year and High School Program

\begin{tabular}{|c|c|c|c|c|c|}
\hline \multicolumn{2}{|c|}{ Skills by Year } & \multicolumn{4}{|c|}{ Skills by High School Program } \\
\hline Year & Skills & Regular & Gifted & $\begin{array}{c}\text { Eta }^{2} \\
\text { Program }\end{array}$ & $\begin{array}{l}\mathrm{Eta}^{2} \\
\mathrm{OAC}\end{array}$ \\
\hline Year 1 & 3.78 & & & & \\
\hline Year 2 & 3.84 & & & & \\
\hline Year 3 & 3.86 & & & & \\
\hline Year 4 & 3.90 & & & & \\
\hline Overall & 3.84 & 3.84 & 3.88 & .00 & .02 \\
\hline Sig. F & .521 & .670 & & & .001 \\
\hline $\mathrm{N}$ & 451 & 398 & 53 & & \\
\hline
\end{tabular}

is .00 and for OAC marks, only .02; however, the latter is statistically significant (.001). In essence, there is virtually no change from one year of study to the next for planning and organizing skills and graduates of gifted programs have no more strength in these areas than other students.

The information in Table 7 shows that like other skills examined, self-assessments of communication skills vary little between first (3.82) and fourth (3.87) years. Similarly, while the scores for graduates of gifted 
Table 7

\section{Communication Skills by Year and High School Program}

\begin{tabular}{|c|c|c|c|c|c|}
\hline \multicolumn{2}{|c|}{ Skills by Year } & \multicolumn{4}{|c|}{ Skills by High School Program } \\
\hline Year & Skills & Regular & Gifted & $\begin{array}{c}\text { Eta }^{2} \\
\text { Program }\end{array}$ & $\begin{array}{l}\mathrm{Eta}^{2} \\
\mathrm{OAC}\end{array}$ \\
\hline Year 1 & 3.82 & & & & \\
\hline Year 2 & 3.81 & & & & \\
\hline Year 3 & 3.88 & & & & \\
\hline Year 4 & 3.89 & & & & \\
\hline Overall & 3.87 & 3.83 & 4.03 & .01 & .00 \\
\hline Sig. F & .366 & .065 & & & .775 \\
\hline $\mathrm{N}$ & 448 & 396 & 52 & & \\
\hline
\end{tabular}

programs (4.03) are slightly higher than those of regular programs (3.83), the differences are not statistically significant. Eta squared for program and OAC marks is only .01 and .00 respectively. Overall, communication skills vary by neither year, high school program, nor OAC marks.

The story is repeated for interpersonal skills as presented in Table 8. Changes between year one (3.78) and year four (3.92) are small and not statistically significant (.705). In addition, the slight differences that exist among graduates of regular (3.83) and gifted programs (3.82) are not statistically significant (.997), and eta squared for program (.00) and OAC marks (.01) are small and not statistically significant.

In the'final table (Table 9) we can examine quantitative and mathematical skills. Although there is a slight increase in scores between year one (3.11) and the final year (3.19) changes are not statistically significant (.069). While students from regular programs (3.14) do not score as high as graduates of gifted programs (3.25), differences are not statistically significant. Moreover, while the eta squared for program is .00 it is a slightly higher (but still low) .09 for OAC marks but the eta squared for OAC marks is statistically significant $(.000)$. In conclusion, only OAC marks have implications for self-assessments of quantitative and math skills.

Overall, the information presented in this section indicates that after controlling for OAC marks, having come from a gifted program only 
Table 8

Interpersonal Skills by Year and High School Program

\begin{tabular}{|c|c|c|c|c|c|}
\hline \multicolumn{2}{|c|}{ Skills by Year } & \multicolumn{4}{|c|}{ Skills by High School Program } \\
\hline Year & Skills & Regular & Gifted & $\begin{array}{c}\text { Eta }^{2} \\
\text { Program }\end{array}$ & $\begin{array}{l}\mathrm{Eta}^{2} \\
\mathrm{OAC}\end{array}$ \\
\hline Year 1 & 3.78 & & & & \\
\hline Year 2 & 3.78 & & & & \\
\hline Year 3 & 3.84 & & & & \\
\hline Year 4 & 3.92 & & & & \\
\hline Overall & 3.83 & 3.83 & 3.82 & .00 & .01 \\
\hline Sig. F & .705 & .997 & & & .095 \\
\hline$\overline{\mathrm{N}}$ & 451 & 398 & 53 & & \\
\hline
\end{tabular}

Table 9

Quantitative Skills by Year and High School Program

\begin{tabular}{|c|c|c|c|c|c|}
\hline \multicolumn{2}{|c|}{ Skills by Year } & \multicolumn{4}{|c|}{ Skills by High School Program } \\
\hline Year & Skills & Regular & Gifted & $\begin{array}{c}\text { Eta }^{2} \\
\text { Program }\end{array}$ & $\begin{array}{c}\mathrm{Eta}^{2} \\
\mathrm{OAC}\end{array}$ \\
\hline Year 1 & 3.11 & & & & \\
\hline Year 2 & 3.12 & & & & \\
\hline Year 3 & 3.18 & & & & \\
\hline Year 4 & 3.19 & & & & \\
\hline Overall & 3.15 & 3.14 & 3.25 & .00 & .09 \\
\hline$\overline{\text { Sig. F }}$ & .069 & .411 & & & .000 \\
\hline$\overline{\mathrm{N}}$ & 422 & 372 & 50 & & \\
\hline
\end{tabular}

affects self-assessments of thinking and reasoning skills and problem solving skills. Moreover, although graduates of gifted programs score themselves higher on these dimensions than graduates of regular programs, differences are not large.

Throughout this analysis no reference has been made to the possibility that the year to year fluctuations in achievement and skills' scores may vary by the type of high school program. For example, although 
there may be little overall year to year fluctuation, is there perhaps a regular increase for graduates of, say, gifted programs? Possibilities like these were not mentioned for the simple reason that in no case was there a statistically significant year to year difference within program categories.

\section{CONCLUSION}

The legislation responsible for the provision of gifted programs in Ontario's schools was based on the assumption that some students had a degree of ability that required "differentiated learning experiences of a depth and breadth beyond those normally provided in the regular program to satisfy the level of potential indicated," and that such students might profit from forms of instruction that are not the norm. Consistent with the intent of the legislation, were the identification process actually able to identify students with superior abilities, we might reasonably expect that these abilities would become evident in post high school pursuits such as university education and careers.

While we have no information on the extent to which participation in a program for the gifted has long term life consequences in areas like careers, we know from this study that gifted students entering York complete slightly more credits than the graduates of regular programs and have slightly better self-assessed thinking and reasoning and problem solving skills; however, they do not get better marks. As a result, we can conclude, given current selection procedures, that in terms of university performance, participating in a gifted program adds little value to what is obtained from a regular high school program. Should this finding be replicated in other universities, it would be possible to view the process in Ontario that results in the conferring on students of gifted labels as questionable. This said, even if the current findings were replicated, we do not know if graduating from a gifted program confers advantages in other realms of endeavour, or later in life. 


\section{References}

Anonymous, (1981). Implications of Bill 82 and regulations pertaining thereof. Ontario Education, 13, March/April.

Baird, L. (1976). Using self-reports to predict student performance. New York, NY: College Entrance Examination Board.

Berdie, R. (1971). Self-claimed and tested knowledge. Educational and Psychological Measurement, 31(3), 629-636.

Dey, E.L. (1997). Working with low survey response rates: The efficacy of weighting adjustments. Research in Higher Education, 38(2), 215-227.

Dumont, R., \& Troelstrup, R. (1980). Exploring relationships between objective and subjective measures of instructional outcomes. Research in Higher Education, 12(1), 37-51.

Evers, F., Rush, J., Krmpotic, J., \& Duncan-Robinson, J. (1993). Making the match: Phase II. Guelph, ON: University of Guelph.

Gardner, H. (1985). The mind's new science. New York, NY: Basic Books.

Gardner, H. (1984). Frames of mind. New York, NY: Basic Books.

Government of Ontario. (1990). Education Act. Toronto, ON: Ministry of the Attorney General.

Grayson, J.P. (1999). The student experience at York University: The effects of income, race, and gender over four years. Toronto, ON: York University, Institute for Social Research

Heller, K.A., \& Feldhusen, J.F. (Eds.). (1986). Identifying and nurturing the gifted. Toronto, ON: Hans Huber.

Hodder, C. (1984). The education amendment act (Ontario) 1980: A review. Interchange, 15(3), 44-53.

Keeton, A. (1983). A consumer's guide to Bill 82. Toronto, ON: OISE.

McMorris, R., \& Ambrosino, R. (1973). Self-report predictors: A reminder. Journal of Educational Measurement, 10(1), 13-17.

Pike, G. (1994). The relationship between self-report and objective measures of student achievement. Presented to the Annual Meeting of the Association for the Study of Higher Education, Tuscon, AZ.

Pike, G. (1995a). Limitations of using students' self-reports of academic development as proxies for traditional achievement measures. Presented to the Annual Meeting of the Association for Institutional Research, Boston, MA.

Pike, G. (1995b). The relationship between self-reports of college experiences and achievement test scores. Research in Higher Education, 36(1), $1-21$. 
Pohlmann, J., \& Beggs, D. (1974). A study of the validity of self-reported measures of academic growth. Journal of Educational Measurement, 2(2), $115-120$.

Renzulli, J.S. (1978). What makes giftedness? Phi Delta Kappan, 60 , 180-184.

Smyth, E. (1984). Educating Ontario's ablest. Special Education in Canada, 58 .

Sternberg, R.J. (1985). Beyond IQ. Cambridge: Cambridge University Press.

Sternberg, R.J. (1990). Metaphors of mind. Cambridge: Cambridge University Press.

Sternberg, R.J, \& Wagner, R.K. (1986). Practical intelligence. Cambridge: Cambridge University Press.

Sternberg, R.J., \& Davidson, J.E. (Eds.). (1986). Conceptions of giftedness. Cambridge: Cambridge University Press

Tannenbaum, A.J. (1983). Gifted children: Psychological and educational perspectives. New York, NY: Macmillan.

Walters, J., \& Gardner, J. (1986). The crystallizing experience: Discovering an intellectual gift. In R.J. Sternberg \& J.E. Davidson (Eds.), Conceptions of giftedness. Cambridge: Cambridge University Press. 